\title{
We are family. The conflict between conservative movements and feminists
}

Elena Pavan, University of Trento

The Version of Record of this manuscript has been published and is available in Contemporary Italian Politics. Date of publication - 20 March 2020,

https://www.tandfonline.com/doi/full/10.1080/23248823.2020.1744892

Between 29 and 31 March 2019, the city of Verona hosted the thirteenth World Congress of Families (WCF) organised by the International Organization for the Family - a transnational coalition which, as its own web site states, came into being 'to unite and equip leaders, organizations, and families to affirm, celebrate, and defend the natural family as the only fundamental and sustainable unit of society'. ${ }^{1}$ In the Palazzo della Gran Guardia, in the heart of the city, speeches were given by a succession of high-profile representatives of the Catholic and Orthodox Churches; representatives of Hungarian, Ukrainian, Russian and African government organisations; intellectuals, journalists, writers, footballers and television presenters - along with high-profile members of the organisations most active in Italy in defending the natural family and in campaigning against abortion and parenthood rights of same-sex couples. Such organisations included Family Day-Comitato Difendiamo i Nostri Figli, la Manif Pur Tous Italia-Generazione Famiglia, ProVita \& Famiglia Onlus, CitizenGo. The official gadget produced for the event was a rubber ten week-old foetus sponsored by ProVita \& Famiglia and given to participants in a small bag bearing the slogan 'Abortion stops a beating heart'. On 31 March, the Congress concluded with a March for the Family, which is estimated to have attracted the participation of around ten thousand people led by representatives of the above-mentioned associations as well as by a number of members of Forza Nuova - a well-known far right party.

From the conference platform, speeches were given by deputy Prime Minister and Minister of the Interior, Matteo Salvini, the leader of Fratelli d'Italia (Brothers of Italy, FdI), Giorgia Meloni, and by a formidable array of politicians belonging to the Lega (League): the Senator Simone Pillon; the Ministers for Education, and for the Family and the Disabled Marco Bussetti and Lorenzo Fontana respectively; the Mayor of Verona, Federico Sboarina; the president of the Veneto region, Luca Zaia, together with his deputy, Gianluca Forcolin; and the regional president of Friuli-Venezia Giulia, Massimiliano Fedriga. There was no representative of the other half of the governing coalition, not least because of the statement made by Luigi Di Maio, who was keen to distance the Movimento Cinque Stelle (Five-star Movement, M5S) from the League which, in his words, was 'in Verona celebrating the Middle Ages'.

Outside the 'red zone' of the Congress - in the premises of various Veronese feminist and transfeminist groups and associations such as il Circolo Pink, il Circolo della Rosa and Sobilla; within independent book shops such as Libre; in the rooms of the Associazione Nazionale Partigiani d'Italia (National Association of Italian Partisans, ANPI), and, above all, in the streets and the squares of the city - the three-day event, Verona Città Transfemminista (Verona, a Transfeminist City) took place. Organised by the movement network Non Una Di Meno (Not One Less, NUDM), the event aimed openly at contesting the WCF. NUDM is a transfeminist movement active in Italy since 2016 in opposition to male violence against women and all forms of gender-based violence. The core of the protest was the march which, on $30 \mathrm{March}$, made its way from the Porta Nuova railway station to the Porta Vescovo station, passing through the city streets and by the venue of the WCF itself - while being kept separate from it by a massive police cordon. Estimates of the size of the

\footnotetext{
${ }^{1}$ https://www.profam.org/mission/

2 https://www.ilfattoquotidiano.it/2019/03/19/congresso-delle-famiglie-di-maio-nessuno-dei-nostri-a-verona-la-legafesteggia-il-medioevo/5048803/
} 
march remain extremely varied: while the Verona police headquarter puts the number of participants at between 25,000 and 40,000, from the megaphones of the NUDM supporters spoke enthusiastically of 100,000.

Far from being an occasion to develop a scientific and critical reflection on the evolution of the family in the contemporary social, political and economic contexts, the WCF functioned rather as a litmus test of the extent to which sex, gender and sexuality remain a central area of conflict in Italian politics - an area within which some actors hold the potential for (re)defining the central pillars of the social and political orders but also to reinforce or undermine alliances between parties inside and outside government. This article outlines the basic contours of this field of contention beginning with the origins of the WCF. It then moves onto considering the nature and mobilisation strategies of the two movement networks opposing each other during the event, and explores some of the principal ramifications of the conflict for Italy's main political parties.

\section{Conflict there is (and it shows)}

There were no episodes of violence involving demonstrators, Congress participants or the police during the three-day events in Verona. Similarly, there were no arrests or instances of damage to property. No one was hurt. Importantly, the events took place in a moment in which Italy had already made a number of important steps towards recognising several forms of partnership particularly through to the so-called 'legge Cirinnà' (L.76/2016), after the name of the Senator of the Partito Democratico (Democratic Party, DC) who promoted it, which gave legal recognition to same-sex couples as 'civil partnerships' and granted some rights also to unmarried life partners. In the three years following the approval of law 76/2016, more than 9,500 civil partnerships were registered and, as the latest Istat report on the topic shows, the number is beginning to 'stabilise' following a spike reached when the law came into force (Istat, 2019: 9). Moreover, a recent study carried out during the last electoral campaign for parliamentary elections shows that the majority of the Italian electorate favours retaining civil partnerships (Emanuele, Maggini and Paparo, 2020). If PD voters tend to be more favourable to such a maintenance than M5S, League and Forza Italia (FI) voters, all respondents agree in giving the issue of civil partnerships a low priority as compared to other matters, especially, immigration, salaries and taxation (ibidem).

Nonetheless, it would be mistaken to equate these elements with the absence or the dying out of a conflict around the issue of the family and, hence, around the issues of sex, gender and sexuality. In Verona, the separation between a militarily patrolled 'red zone' given over to the Congress, and the venues of the march and the transfeminist initiatives made clear the persistence of an irreconcilable clash between opposing perspectives not only on what does and does not constitute a family but, more generally, on the system of vales, right, duties, obligations and possibilities defined around the concepts of sex, gender and sexuality. As we shall see in more detail in the sections that follow, such conflict was especially intense during the threeday events in Verona, counter-posing, as they did, the initiatives in defence of the natural family, on the one hand, and those taking place under the transfeminist umbrella of NUDM, on the other. However, the conflict also sucked in the parties of the yellow-green government. Indeed the decision to hold the WCF in Verona gave rise to a series of frictions between the League and the M5S, bringing to light a series of divisions within the governing coalition concerning the issues addressed by the Congress as well as the individuals and groups that helped to organise it.

Such divide deepened not only with regards to the participation of members of the Government in the event, but above all, as a consequence of its alleged sponsorship by the Prime Minister's office. Initially, the Verona Congress web site claimed to be sponsored by 'the Prime Minister's Office and the Ministry for the Family and the Disabled'. However, in a Facebook post on 21 March 2019, the Prime Minister Giuseppe Conte clarified that 'sponsorship to the WCF [had] been given by the Minister for Families and the Disabled, Lorenzo Fontana, on his own initiative, in accordance with his own prerogatives, without my personal involvement or that of the Government collectively'. ${ }^{3}$ He further clarified he had asked the Minister to delete the reference to the Prime Minister's office and specified that, while the Government did 'not have a specific view on the issues

${ }^{3}$ https://www.facebook.com/GiuseppeConte64/posts/593415124473790 
to be discussed at the Congress', it 'would to do its utmost to safeguard the family based on marriage, without in any way allowing this to compromise the legal recognition and the complete legitimacy of civil partnerships and the diverse forms of cohabitation based on affective ties' ${ }^{4}$ Upon the announcement of the revocation of the sponsorship, the organisers of the Verona Congress published a press release in which they stated that they had not the slightest interest in the 'little logo' of Palazzo Chigi (the headquarter of the Prime Minister). Rather, what they were interested in was the fundamental overlap between the views expressed by Conte, who clearly linked the family and marriage, and those expressed by the WCF. ${ }^{5}$

Beyond what happened in Verona, it should not be forgotten that the rapid approval of the 'legge Cirinnà' (which took about a year) cannot be considered indicative of a genuinely greater acceptance of LGBTI people and their rights in Italy. This law was in fact approved after twenty years of effort which had failed to produce any results largely because of a general inability to manage the politics of what Cavalletto (2017:216) calls a 'matter of conscience' which had always been considered, on both the right and the left, as 'not urgent' precisely for its contentious nature. Moreover, on close inspection, law 76/2016 provides for recognition of same-sex couples by means of a legal instrument - civil partnerships - which is different from and accords fewer rights than the egalitarian institution of marriage between spouses. This is particularly true when it comes to relations of kinship and the inability of same-sex couples to adopt children (ibidem). Finally, in spite of these innovations, Italy continues to occupy a rather low position within international rankings concerning the recognition of LGBTQI rights. This is revealed particularly by the Rainbow Index compiled by the International Lesbian, Gay, Bisexual, Trans and Intersex Association (ILGA-Europe), which places Italy at the $35^{\text {th }}$ place out of 49 countries in terms of the 'positive impact' of current legislations on the quality of life of LGBTI people (ILGA-Europe, 2019).

\section{At the root of the conflict. The emergence of the World Congress of Families}

The World Congress of Families does not openly qualifies as a political event. Rather, as the name suggests, it claims to have a scientific purpose. In fact, the origins of the Congress can be traced back to the meeting between two scholars, Anatoly Antonov - director of the Department of Demography and Sociology of the Family of the Lomonosov Moscow State University - and Alan Carson - historian, and since 1986 president of the ultra-conservative Rockford Institute think-tank. ${ }^{6}$

In 1988, Carson published the volume, Family questions: reflections on the American social crisis, in which he linked the 'decline' of the American society since the 1970s to the demographic decline which, in turn, followed from a number of factors: the growing use of contraception and the legalisation of abortion; the reduction of the number of marriages, and the growth of female employment outside the family. According to Carson, all these factors were directly connected with the radical distortion of 'female values' system perpetrated by the feminist movement, which had begun to re-emerge in the States since the end of the 1960s. In his view, under the negative influence of feminists, women were increasingly distancing themselves from their 'natural role' of mothers and wives, increasingly directing their attention on matters outside their home, in the public sphere, thus depriving the American society of new energy and increasingly exposing it to the risk of ethnic replacement.

Carson's 'theories', mostly discredited by his American academic colleagues, had instead found in Anotonov a strong supporter. Long engaged in efforts to re-establish the primacy of the 'natural family' in the Russian society, in 1995 Antonov invited Carson to Moscow for a series of seminars and meetings. Here, the two conceived the idea of a 'congress' to push to the top of the contemporary political agenda the institution of the family - as composed by a father, a mother and their offspring.

\footnotetext{
4 ibidem

${ }^{5}$ https://www.provitaefamiglia.it/blog/wcf-verona-xiii-gli-organizzatori-loghetto-non-ci-intriga-conte-nella-sostanzacome-noi

${ }^{6}$ A very detailed account of the origins of the World Congress of Families can be found on the blog Playing the Gender Card https://playingthegendercard.wordpress.com/2019/03/09/world-congress-of-families-le-radici-ideologiche/.
} 
Following these meetings, the first World Congress of Families was held in Prague in 1997. The final declaration asserted that 'in many democratic countries, cultural revolutions, materialism and sexual permissiveness have resulted in a destruction and denigration of moral values, thereby producing hedonistic societies in which extra-marital relationships, adultery and divorce proliferate leading to widespread abortion, illegitimacy and single-parent children" (WCF 1997, §4). Thereby, the Prague WCF cemented an alliance between the ultra-conservatives of the western Catholic Church and the Orthodox Church, as well as between them and the anti-communists of the post-Soviet countries. The declaration also affirmed that 'the family [is] a man and a woman bound in a lifelong covenant of marriage, as ordained by God, for the purpose of: 1 . providing support, protection, love and companionship for both husband and wife; 2 . satisfying of male/female sexuality; 3 . welcoming and nurturing of children; 4. the continuation of the human race' (ibidem, §11). At the base of the family as 'the most important social unit', the declaration claimed, stands 'the complementary nature of men and women [which] is rooted in the psychological and physical differences between the sexes'. To conclude, the declaration called upon 'all governments and the United Nations to promote policies in support of the traditional family' (ibidem, $\S 12$ e $\S 21)^{7}$

The thirteenth WCF in Verona stands directly in line with this first meeting - carrying on an inheritance that has been consolidating over the past twenty-five years through a series of meetings held irregularly until 2012 and, since then, on an annual basis. Albeit maintaining a focus on the natural family, defined in accordance with its own tradition as 'the only fundamental and sustainable unit of society', the discussion during the Verona Congress covered eight specific topics: the beauty of marriage; children's rights; integral human ecology; the woman in history; growth and demographic decline; woman's dignity and health; legal defence of life and family; policies promoting birth-rate and families. ${ }^{8}$ In this sense, the idea of the natural family functioned, in Verona as much as it did in the past, as a cover for discussing a whole series of issues concerning sex, gender and sexuality (and, hence, the role of women and LGBTQI people) as elements that structure the social and political order.

Along the lines of their interpretation, signification and transposition into legal provisions, 'family issues' lose their alleged scientific quality and become genuinely contentious political matters. At the heart of the conflict between supporters of the natural family and NUDM lays the assumption, clearly endorsed in the final declaration of the WCF in 1997, that there exists a natural sexual dimorphism - that is, only two sexes do exist and are distinguished by contrasting physical, genetic and psychological characteristics. In turn, the existence of two biologically distinct sexes provides the basis for a natural division of individuals into two genders - male and female - with different roles in the public and private spheres as well as with different opportunities, rights and obligations. This essentialist vision is very deeply rooted in Italy - particularly as a consequence of the influence of the Vatican in the country's politics, especially when it comes to issues around bio-ethics, sexuality and education (Garbagnoli, 2017). More broadly, it constitutes the shared premise driving the actions of all those associated with the WCF regardless of where they come from or whether they represent public, religious or civil-society institutions.

The feminist movements of the 1960s played a crucial role in questioning the assumption that biological sex inevitably shapes a social and political order founded on hierarchical relations between just two possible genders. In fact, feminist protests contributed decisively to the de-naturalisation and the politicisation of the notion of sex itself (Hawkesworth, 2013). Similarly, feminists theorized the concept of gender to uncover 'the specific cultural characteristics associated with masculinity and femininity' and the social construction of inequality between the genders (ibidem, p. 36). Subsequent phases of mobilisation, often labelled (not without problems) as 'feminist waves' (Evans and Chamberlain, 2015), broadened the horizon of the feminist gaze beyond a binary vision of gender thus embracing the demands for liberation and the struggles against discrimination of the LGBTQI community. In this way, gender analysis widened its scope and revealed the range of circumstances in which men and women find themselves acting within biased opportunity structures

\footnotetext{
${ }^{7}$ Ibid.

${ }^{8}$ https://wcfverona.org/it/about-the-congress/
} 
that underpin inequalities of gender, class, race and ethnicity, physical ability and religious belief. Feminist mobilizations also had significant cultural and political consequences in the Italian context. By placing the issue of gender inequality at the centre of public debate and - through such conquests as the right to abortion and divorce and the recognition of same-sex couples - they undermined some of the central pillars of the natural order that had for long governed Italian society and politics.

In light of all the challenges posed and the achievements obtained by feminist and LGBTQI activism, the numerous supporters of the essentialist view embodied in the idea of the natural family were obliged to change the ways in which they sought to advance their positions. At the beginning of the 2000s, gender was conceived by the Vatican (with the help of a series of 'experts' in gender and sexuality) as a 'rhetorical device' aimed at preserving existing power relations within a secular society heavily influenced by the conquests of the (trans)feminist movements (Garbagnoli and Prearo, 2018).

Gender is a term that is never translated from English precisely to preserve its extraneousness from the everyday life based on a natural order. It refers to the existence of an alleged ideology invented by female academics belonging to an 'oppressive minority consisting of the feminist-homosexual-Marxist elites' (Bellè and Poggio 2018: 122) with the aim to 'pervert' the concepts of sex, gender and sexuality. Used to evoke the dramatically negative consequences of abandoning the natural order, the gender device is designed to reestablish sexual dimorphism as a natural assumption but with a positive glow - essentially by celebrating the 'anthropological complementarity' between men and women in a context in which it is no longer possible to refer explicitly to an 'hierarchical order of the family [or to] the natural subordination of women to men' (Garbagnoli and Prearo, 2018: 21-23). In short, the gender device has been deliberately constructed to reestablish a hierarchy between the sexes by means of a positive rhetoric. On the one hand, it insists (because it cannot do otherwise) on the equal dignity of men and women while, on the other, it justifies a difference in roles and possibilities based on the natural specificity, physical and moral, of women - a specificity that is effectively captured by the paired concepts 'mother' and 'wife'.

In recent years, this top-down engineered device has performed excellently as a 'master frame' (Snow and Benford, 1992) for remobilising conservative activists inspired by Catholicism. Its reactionary characterunderstood both as a 'reaction to a theoretical and political revolution [and as] an argumentative device for reestablishing the essentialist vision that such a revolution had targeted and breached' (Garbagnoli and Prearo, 2018: 12) - revamps the activism of those Catholics who feel themselves defrauded by the 'post-1968 attack on freedom' (Ibidem, 68).

\section{At the centre of the conflict. The networks of NUDM and of the anti-gender protest}

With the combined presence of WCF activists and the NUDM activists, for three days Verona became a site of open conflict between two opposing movements. On the one hand, there was a movement geared to defend self-determination rights with respect to human identity and the human body, and which opposed all forms of violence (physical, psychological, economic, obstetrical, symbolic) and of oppression stemming from a 'natural' view of the world and, therefore, from naturally hierarchical relationships between genders. On the other hand, there was a movement, conservative in nature, seeking to defend the natural family. Revitalised by the so-called 'struggle against the gender ideology', this movement revived a traditional view of the sexed and sexual order based on the 'anthropological complementarity' of two genders - male and female - understood as the only possible genders (Prearo 2017). Neither of the two were monolithic actors. On the contrary, they were genuine collective action networks bringing together a wide range of actors in support of shared action programmes based on common interests (Diani, 1992). Both networks reached Verona with their own agendas and, at the same time, their own histories of activism.

The origins of the NUDM movement can be traced to the activism of Ni Una Menos, which started in Argentina in 2015 and in overt opposition to male violence against women and to all forms of gender-based violence. As its name suggests, Non Una Di Meno maintained strong links with the Argentinian movement. However, it established itself in Italy as a collective point of reference for the struggle against all forms of 
gender-based violence, demanding full recognition of all genders, the defence of reproductive rights (especially of the law 194 on abortion) and the recognition of the caring role played by women within the domestic sphere.

A particularly significant moment for the consolidation of NUDM came in June 2016 with the brutal murder to a young woman, Sara Di Pietrantonio, on the outskirts of Rome at the hands of the girl's partner. Owing to its extreme brutality, the killing held the attention of the media and the public for a long time. However, the narrative developed by the mainstream media strongly framed the killing as a case of 'romantic love' having ended tragically, more often criticising the victim for have 'chosen the wrong person' than her killer. In explicit opposition to this type of portrayal - held to be complicit in the maintenance of a cultural climate conducive to the spread of gender-based violence (Giomi and Magaraggia, 2017) - a series of initiatives were launched in the Rome area to promote meetings and discussions concerning male violence against women and gender-based violence.

Three organisations acted at the forefront of these initiatives: the Io Decido (I Decide) network, which campaigns against gender-based violence and for the right of all to health; the Unione Donne in Italia (the Union of Women in Italy) - an organisation with a long history of campaigning for women's rights in Italy with roots going back to the Resistance; and the D.i.Re network (Donne in Rete contro la violenza, the Women's Network against Violence), which brings together voluntary associations run by women opposing male violence. The three organisations were united in the effort to draw attention onto gender-based violence as an inherent aspect of all spheres of existence, public and private, rooted in a patriarchal and heteronormative culture. They gave rise to a wave of protest in Italy stimulated by the Argentinian example and called it a 'journey to be undertaken all together' thus broadening participation to include all organisations, formal or informal, committed to the struggle against gender-based violence. ${ }^{9}$

The first objective of the NUDM network was the drawing up of a Feminist Plan to combat both male violence against women and all forms of gender-based violence. ${ }^{10}$ This Plan was drafted by adopting a horizontal form of collaboration structured through a series of 'thematic roundtables' aimed at discussing and uncovering the transversal nature of violence and focussed on legal and juridical aspects, on work and welfare, on health and reproductive rights, on education and migration, on the reporting of violence in the media, on sexism within social movements, on issues of the body, environmental sustainability and living conditions in urban areas. In this way, the Plan, presented at the NUDM national rally in 2017, crystalized the movement's analytic strategy and helped to place the phenomenon of gender-based violence at the crossroads between structural and cultural inequalities (Pavan and Mainardi 2018).

On the other side of the battle lines, there was the network of conservative activists inspired by Catholicism, which had come together around a shared opposition to the 'gender ideology'. As is the case with NUDM, the network of Italian anti-gender activists finds its roots in a protest originating abroad - in this case France, where public discussion about the dangers of gender-oriented educational programmes in primary schools was already very animated (Garbagnoli and Prearo, 2018). However, in contrast with the case of NUDM, the Italian anti-gender protest initiated in 2013 by linking the network's initial claims with a tough opposition to two policies, namely, the 'Decreto Scalfarotto' aimed to combat gender-based discrimination, and the above-mentioned 'legge Cirinnà'.

Rank-and-file anti-gender protestors fall into two distinct but complementary categories. On the one hand, there are recently formed groups set up specifically to combat the 'gender ideology'. On the other hand, there is a more radical component consisting of already-active anti-abortion, conservative Catholic organisations coming from the Italian far right (Garbagnoli, 2017). An especially illustrative example of the actors belonging to the first category is the association La Manif Pour Tous Italia-Generazione Famiglia (LMPTI), directly inspired by its French counterpart, La Manif Pour Tous, which opposes educational programmes concerning gender-related issues in primary schools. Playing a leading role in the initial antigender protests, LMPTI soon became a point of reference for the Italian movement acting as an umbrella

\footnotetext{
${ }^{9} \mathrm{https}: / /$ www.facebook.com/pg/nonunadimeno/about/?ref=page internal

${ }^{10}$ https://drive.google.com/file/d/1r_YsRopDAqxCCvyKd4icBqbMhHVNEcNI/view
} 
organisation for various groups including the Forum delle Associazioni Familiari (the largest of the Catholic family associations), the more recently created committees for the defence of the natural family (such as the Comitato Difendiamo i Nostri Figli) and Catholic associations with close links to the extreme right (such as, for example, Milithia Christi and Alleanza Cattolica) (ibidem).

Those parts of the network associated with pro-life activism saw in the struggle against the 'gender ideology' an opportunity to reinvigorate their campaigns and to pursue the anti-abortion struggle in 'more socially acceptable' ways (Garbagnoli, 2017: 158). Independent of the Movimento per la Vita, a long-standing Italian pro-life organisation (Avanza, 2018), these parts of the anti-gender network are led mainly by three groups: Scienza e Vita, founded in 2007 and one of the first groups to mobilise in direct opposition to the gender idea, Giuristi per La Vita, and Notizie per la Vita, both founded in 2012 as Italian branches of international and transnational anti-abortion and anti-LGBTQI organisations (Garbagnoli, 2017). This component too has strong links with various expressions of the Italian far right: with the League, FdI and Forza Nuova, but also with right-wing national Catholic associations and various transnational movements of a reactionary kind (such as the Brazilian 'Tradition, Family and Private Property' movement) (ibidem).

Animated by a wide range of concerns, the transfeminist networks and the groups opposed to the 'gender ideology' adopt a correspondingly wide range of action strategies which, as we shall see in the next section, were able to find a synthesis in the events surrounding the WCF in Verona.

\section{Between public squares and congresses. The repertoires of protest}

The decision to stage the WCF speaks loudly about a type of action that is typical of the networks of collective action of the anti-gender movement, that is, the organisation of events of scientific nature where assumptions concerning the natural quality of the two sexes and of their anthropological complementarity can be reaffirmed. Such actions are not confined to the organisation of transnational events such as the one in Verona. They include, more often, informal events leading to the moulding and recruitment of new activists by placing them, male and female, in direct contact with the 'experts' who frequently are the leaders of the organisations driving the movement, such as, for example, the spokesperson of Family Day-Comitato Difendiamo i nostri figli, the neuro-surgeon, Massimo Gandolfini, or the defence-lawyer, Gianfranco Amato, president of Giuristi per la Vita.

Field research reveals the existence of a specific format for these events, which often begin with a review of the biological, genetic and anthropological premises, laid out according to Catholic assumptions, of sexual difference. They then proceed with an illustration of the fundamental principles of the 'theory of gender' and of the risks associated with it, and conclude with a call to direct action 'to counter the spread of the gender ideology' (Garbagnoli and Prearo, 2018: 52-53). Moreover, dissemination activities often go hand in hand with efforts to raise awareness, such as those associated with the publication of Quaderni di Scienza e Vita (Books of Science and Life) founded, as the organisation's web site states, 'to deepen our understanding of the delicate relationship between scientific progress and respect for human life'. ${ }^{11}$

Alongside this first type of action, aimed at creating a cultural climate favourable to its demands, the anti-gender network also adopts repertoires more closely associated with forms of collective participation, such as marches and other events organised in public places. The organisation of direct-action protests continues to be a divisive issue within the network, which remains split concerning the effectiveness of these tactics given the progressive re-branding of the pro-life, anti-abortion and anti-gender cause that has been undertaken in order to shield it from the negative connotations of misogyny, reaction and fundamentalism (Avanza, 2018). Despite this, the network of Catholic activists regularly stages genuine protests - as in the case of the March for the Family, which concluded the Verona Congress on 31 March 2019 - though these hold some rather peculiar characteristics. In fact, anti-gender protests tend to have a festive character (Paternotte and Kuhar, 2017; Prearo, 2017). At the crossroads between internal divisions and the desire to distinguish their protests from those of the feminist, the decision to stage events of this kind follow from a very

\footnotetext{
${ }^{11}$ http://www.scienzaevita.org/consultare-i-quaderni-di-sv/
} 
specific strategy. On the one had the festive character of these protests makes it possible to involve young people, adults, women, men, the elderly and children in activities that are perceived as low-risk and, therefore, legitimate. On the other hand, the support of political and religious élites for the anti-gender cause favours peaceful forms of protest in virtue of the greater possibilities for influencing decision-making processes which such support brings (Rucht, 1996).

The desire to ensure that protests are peaceful means that they require considerable organisational effort - as was the case with the Verona march. Indeed, this involved the identification of a route, in a central location, that was sufficiently long as to convey the idea of ample participation but at the same time short enough to maintain a high level of involvement. It also involved the organisation of platform speeches that would combine the authoritative voices of the leaders of the movement with the putting-on-display of 'happy' natural families. It finally required an initial screening of the banners brought to the demonstration which was carried out in collaboration with the police General Investigations and Special Operations Division (the Italian Digos) to ensure that the banners carried 'positive messages without any references to political parties'. ${ }^{12}$

Direct action is, in contrast, the predominant type in the repertoire of action of NUDM, captured in the movement's slogan, 'state of permanent agitation'. As mentioned earlier, it was through the organisation of a national march in 2016, that NUDM became organised and acquired a presence as a collective actor on the Italian political stage. The protest of 30 March 2019, starting from the Verona Porta Nuova railway station and ending at Verona Porta Vescovo station was organised along the same lines as the annual march which takes place in Rome around the key date of 25 November, the International Day for the Elimination of Violence Against Women. Each year, the national march makes it possible for all the local expressions of NUDM to come together and is organised with the aim of reaffirming the movement's commitment to oppose violence while adapting it to current political circumstances. Moreover, the movement tends, ever more often, to conclude its local and regional assemblies with a march as a means of bringing to public attention the main points on which the movement seeks to focus, thus gaining in strength.

In addition to the annual march, NUDM organises two other kinds of events. On the one hand, it mobilises small-scale protests in reaction to specific political developments. In 2019, the most high-profile of these were: the demonstrations that took place in a number of cities on 28 September to mark International Safe Abortion Day; the involvement of the network in the Global Climate Strike of 27 September; the 1 November rally in solidarity with the Kurdish people, and the protests organised during the summer against the Decreto Sicurezza (Security Decree) passed by the yellow-green government. Each small-scale protest is informed by the idea that there is a very close link between gender-based violence and policies to control, if not directly to combat, flows of migration, where the common element is exploitation of people's bodies, personal experiences and precarious circumstances. On the other hand, NUDM organises a feminist strike to coincide with the wide range of other protests that take place around the world to mark International Women's Day. The feminist strike involves calling upon women to abstain from all work and caring activities as a means of drawing attention to the multiple forms of discrimination and violence that affect them every day in both the spheres of economic production and social reproduction (Arruzza, Fraser and Bhattacharya, 2019).

\section{Alliances associated with the conflict. The anti-gender network and its close ties with the League}

As mentioned, the conflict over the issues of sex, gender and sexuality, which placed the anti-gender networks and NUDM on opposite sides in Verona, was not confined to the Congress venue or the streets, but also had reverberations within the yellow-green government. The M5S and the League in fact had opposing attitudes to the Congress. The former distanced itself totally, refusing to participate and severely criticising it - though without going beyond general assertions about the reactionary character of certain view-points expressed during the event and without questioning the implicit model proposed by it.

In contrast, the League's participation both in the organisation and in the deliberations of the WCF testifies to the long-standing alliance between the party and conservative associations inspired by Catholic

\footnotetext{
12 https://wcfverona.org/it/marcia-per-la-famiglia/\#1551544962798-b38d4c37-6ace
} 
ideas in Italy. The choice of Verona as a venue for the event was surely the result of these pre-existing alliances. In fact, before being elected to the Chamber of Deputies and appointed Minister for the family and the disabled, Lorenzo Fontana had been a municipal councillor and deputy mayor of Verona in the Sboarina administration which passed the 2018 motion 'Verona città per la vita' (Verona, a pro-life city), presented by League councillor, Alberto Zelger, and aimed at financing initiatives against abortion. Throughout his political career, Fontana has sought to emphasise the anti-gender implications of the League's populism, especially by campaigning to restrict the right to abortion (in order to combat the falling birth rate) and to defend the natural family (by providing incentives to married couples to have more children). Once appointed as Minister, he even denied the existence of 'rainbow families'.

As Donà (2019) notes, it is not surprising to find significant overlaps between the substance of the Verona Declaration adopted at the end of the WCF so strongly advocated by Fontana, and certain key themes of the League's 2018 election manifesto. These include an insistence on the family as 'the fundamental unit of society' and as a primary place for the education of children; on appropriate public policies and financial incentives to support Italian families; on the heterosexual nature of parenthood, and on the need to re-establish official recognition of the 'natural' roles of mother, father, husband and wife as opposed to 'such generic terms as parent 1 and parent $2{ }^{\prime}{ }^{13}$

The Verona Declaration's insistence on the rights of children echoed another theme underpinning the alliance between the League and the anti-gender network: their common struggle against the so-called 'gender ideology'. The final declaration of the Verona WCF stated that children had the right 'To be respected in their nature and supported in developing an integral sexuality consistent with biology' as well as 'To be protected in their innocence from early sexualization, too often imposed on them at school, on television, and on the Internet' (CMF 2019, §2). One of the measures taken in recent years to protect the rights of children was Marco Bussetti's ministerial circular in 2018 which made the informed consent of parents a prerequisite for their children's participation in extracurricular activities provided for by each school's Piano Triennale dell'offerta Formativa (Three-year plan for educational provision). Amongst these, were the activities outlined by law 107/2015 (better known as the 'Buona Scuola' [Good School] reform) through which the Renzi government sought to work towards 'equality between the sexes and the prevention of gender-based violence and all forms of discrimination' (L. 107/2015, article 1, sub-section 16).

However, Verona provided other obvious signs of the close alliance between the League and the antigender network - especially through the participation of Senator Simone Pillon, who had sponsored disegno di legge (legislative proposal) n.735, better known as the ' $d d l$ Pillon'. This provision aimed at introducing a series of changes to family law as well as to the law governing separation and the custody of children. The main pillars of the $d d l$ Pillon had already been included in the League's election manifesto and were written into the contract for government signed by both the League and the M5S without modification. The proposal, which was subject to a number of hearings and debates in the Senate's Judicial Committee, introduced changes in four main areas: compulsory, chargeable, mediation for couples intending to separate; equal rights of access to children for both parents; an obligation on both parents to provide, directly, for the maintenance of children; measures to combat parental alienation. The proposal's intended purpose was to 'remove family conflict from the purview of the courts and [...] place responsibility back on the family and parents' (Siviero, 2018: 22). However, it provoked strong opposition, both inside and outside Parliament, including the opposition of NUDM, and was read as a victory of the Italian anti-gender movement to which Senator Pillon - a member of the Family Day-Comitato Difendiamo i Nostri Figli (from which he had temporarily resigned) - was certainly no stranger.

\section{Conclusions}

\footnotetext{
${ }^{13}$ See the section on the family - 'Famiglia' - of the League's manifesto available at https://www.leganord.org/component/phocadownload/category/5-elezioni?download=1514:programma-lega-salvinipremier-2018
} 
Through the organisation of what was purportedly a scientific gathering, the Verona Congress reignited a conflict that was hidden beneath the smokescreen of a discussion about the family, but which had never died out. In Italy, as in the rest of the world, the conflict entailed a clash between diverse social realities. On one side, there were those who held to a traditional conception of the family as an institution based on a hierarchical relationship between only two possible sexes. On the other side, there were those who demanded the right to self-determination of the physical body as well as of social identities, and an end to all forms of discrimination based on sex, gender and sexual preferences and orientations. In concluding, it is important to emphasise that the Verona Congress reactivated the conflict; it did not create it. As illustrated in this article, the conflict around issues of sex, gender and sexuality, as much as around the rights of women and the LGBTQI community is long-standing. It is deeply rooted (especially in the Italian case) in a cultural and value system heavily influenced by the powerful presence of the Vatican and the conservative world of the Catholic associations.

The Verona Congress played an important role in directing public attention to diametrically opposed worldviews and political projects connected to divergent views of sex, gender and sexuality. It offered a valuable opportunity to begin to look more closely at the wide range of actors - formal organisations and groups; networks and movements; parties and institutions - driving the conflict, and at the complex reactions uniting them.

Since the end of the three-day events in Verona, the main substance of the conflict has remained unchanged despite the arrival in office of the second Conte government. As shown by the organisation of its national demonstration on 23 November 2019, NUDM continues its struggle to end male violence against women, and all forms of gender-based violence. It remains independent of the political parties. When contacts are established between the movement and Italian political parties, as happened with Laura Boldrini's participation in the demonstration of 30 March, they are more often than not driven by the personal individual convictions rather than by any broader programmatic overlap.

On the other hand, the political and intellectual bonding between the anti-gender network and the Italian right - especially the League but also FdI and Forza Nuova to a large extent - remains solid notwithstanding the occasional set-back such as the new yellow-red government's ditching of the Pillon decree. On various occasions - for example during the centre-right's rally in piazza San Giovanni on 19 October 2019 - political leaders like Salvini and Meloni have used narratives showing that they have adopted wholesale the frames, demands and repertoires of action of the anti-gender movement. Placing religious symbols and reminders next to the Italian flag on the platforms from which they speak, the leaders of the right have made clear their rejection of parenthood rights for same-sex couples and insisted on 'defence of the rights of children'. By their side, as with the Family Days of the past, strictly married, heterosexual and Italian parents, and their children, communicate the sense that they 'need' political actors and policies that will defend Italian families from what the Final Declaration of the WCF in Verona referred to as a 'moral and economic crisis'.

While the venue for the next Congress remains to be announced, the conflict continues to take its course - this against the background of the increasingly uncertain social and political context that characterises Italy at the beginning of 2020 .

\section{References}

Arruzza. C., T. Batthacharya and N. Fraser (2019), Femminismo per il 99\%. Un manifesto, Bari: Laterza.

Avanza, M. (2018), 'Plea for an Emic Approach Towards 'Ugly Movements': Lessons from the Divisions within the Italian Pro-Life Movement', Politics and Governance, vol. 6, n.3, pp. 112-125. 
Bellè, E. and B. Poggio (2018), 'New Faces of Populism: The Italian Anti-Gender Mobilization, in Populism on the Loose', in E. Palonen, Emilia, U. Kovala, T. Saresma, and M. Ruotsalainen (eds), Jyväskylä: University of Jyväskylä Press, pp. 119-142.

Cavaletto, G.M. (2017), 'La legge sulle unioni civili e la pluralizzazione delle forme familiari', in Politica in Italia 2017. I fatti dell'anno e le interpretazioni, A. Chiaramonte and A. Wilson (eds), Bologna: Il Mulino, pp. 204-214.

CMF - Congresso Mondiale delle Famiglie (2019), Dichiarazione Finale. Available at https://www.provitaefamiglia.it/blog/dichiarazione-finale-del-wcf-verona-2019 (last accessed 10 January 2020).

Diani, M. (1992), 'The concept of social movements', The Sociological Review, vol. 40, n. 1, pp. 1-25.

Donà, A. (2019), 'The populist Italian Lega from ethno-regionalism to radical right-wing nationalism: backsliding gender-equality policies with a little help from the anti-gender movement', European Journal of Politics and Gender, pp. 1-3. DOI: 10.1332/251510819X15657567135115.

Emanuele, V., N. Maggini and A. Paparo (2020), 'The times they are a-changin': party campaign strategies in the 2018 Italian election', West European Politics, pp. 665-687. DOI: 10.1080/01402382.2019.1655966.

Evans, E. and P. Chamberlain (2015), 'Critical waves: Exploring feminist identity, discourse and Praxis in Western feminism', Social Movement Studies, vol. 14, n.4, pp.396-409.

Garbagnoli, S. (2017), 'Italy as a lighthouse: Anti-gender protests between the "anthropological question" and national identity', in Anti-Gender Campaigns in Europe: Mobilizing against Equality, R. Kuhar and D. Paternotte (eds), London/New York: Rowman and Littlefield, pp.151-174.

Garbagnoli, S. and M. Prearo (2018), La crociata «anti-gender» dal Vaticano alle manif pour tous, Torino: Kaplan.

E. Giomi and S. Magaraggia (2017), Relazioni brutali. Genere e violenza nella cultura mediale, Bologna: Il Mulino.

Hawkesworth, M. (2013), Sex, Gender, and Sexuality: From Naturalized Presumption to Analytical Categories, in The Oxford Handbook of Gender and Politics, G. Waylen, K. Celis, J. Kantola, and S. L. Weldon (eds), Oxford: Oxford University Press, pp.31-56.

ILGA-Europe (2019), Rainbow Index - May 2019. Available at https://ilgaeurope.org/sites/default/files/Attachments/rainbowindex2019online_0_0.pdf (Last accessed 10 January 2020).

ISTAT (2019), Matrimoni e Unioni Civili - 2018, pp. 1-13. Available at https://www.istat.it/it/files/2019/11/Report_Matrimoni_Unioni_Civili_2018.pdf (Last accessed 10 January 2020).

Paternotte, D. and R. Kuhar (2017), 'The anti-gender movement in comparative perspective', in Anti-Gender Campaigns in Europe: Mobilizing against Equality, R. Kuhar and D. Paternotte (eds), London/New York: Rowman and Littlefield, pp.253-276. 
Pavan, E. and A. Mainardi (2018), 'Striking, Marching, Tweeting. Studying how online networks change together with movements', Partecipazione e Conflitto, vol. 11, n.2, pp. 394-422.

Prearo, M. (2017), 'La politica identitaria dell'attivismo anti-gender: un'ipotesi micro-analitica', in Saperi di Genere. Prospettive interdisciplinari su formazione, università, lavoro, politiche e movimenti Sociali, A. Murgia and B. Poggio (eds), Università di Trento, pp. 792-804.

Rucht, D. (1996), 'The Impact of National Contexts on Social Movement Structures: A Cross-Movement and Cross-National Perspective', in Comparative Perspectives on Social Movements, D. McAdam, J.D. McCarthy and M.N.Zald (eds), Cambridge: Cambridge University Press, pp. 185-204.

Siviero, G. (2018), 'Il ddl Pillon, spiegato bene', in I nostri corpi come anticorpi, B. Brignone and F. Druetti (eds), Gallarate: People, pp. 21-42. 